\title{
Türkiye'de Aile Çiftçiliği, İşgücü Prodüktivitesi ve Sürdürülebilirlik
}

\author{
Gülşen KESKiN ${ }^{1 *}$, Gülzade KAPLAN ${ }^{1}$, Hayati BAŞARAN ${ }^{2}$ \\ ${ }^{1}$ Gıda Tarım ve Hayvancılık Bakanlığı, Ankara \\ ${ }^{2}$ Gümrük ve Ticaret Bakanlığı, Ankara \\ *Sorumlu yazar: gülsenkeskin@gmail.com
}

Öz

Tarımda aile işletmeleri dünyadaki tüm tarımsal işletmelerin yaklaşık \%98'ini oluşturmakta ve tarımsal üretimin \%56'sını gerçekleştirmektedir. Türkiye'de de tarımsal üretimin ana kaynağını aile işletmeleri oluşturmakta ve 3 milyon işletmede yaklaşık 5.5-6 milyon kişiye istihdam imkanı sağlanmaktadır. Türkiye tarım sektörü, GSYH'nin (Gayri Safi Yurtiçi Hasıla) yaklaşık \%7.5'unu ve istihdamın \%21'ini oluşturmaktadır. GSYH'daki payın düşüklüğü ve yüksek istihdam oranı tarımdaki verimliliğin düşüklüğünü göstermektedir. Bu durum birçok faktörün yanı sıra küçük tarım işletmelerinin yoğunluğu, tarımda ekonomik örgütlenmedeki etkinsizlik, ileri teknoloji kullanımının tüm çiftçiler düzeyine yaygınlaşmaması, kırsal alanda eğitim, sağlık gibi sosyal imkanların azlığı ve kaynakların etkin kullanılmamasının sonucu olarak ortaya çıkmaktadır. Bu çalışmada, Türkiye'de aile çiftçiliğinin mevcut durumu ve işgücü verimliliği dikkate alınarak tarımsal üretimde sürdürülebilirliğin sağlanma koşulları incelenmektedir. Bu amaçla, Türkiye'de aile çiftçiliğinin güçlü ve zayıf yönleri anlatılarak, tarımdaki yapısal sorunların çözümünde ve aile çiftçiliğinin zayıf yönlerinin giderilmesinde ekonomik bir örgütlenmenin gerekliliği anlatılmakta ve çözüm önerileri sunulmaktadır.

Anahtar Kelimeler: Aile çiftçiliği, Prodüktivite, Sürdürülebilirlik

\section{Family Farming In Turkey, Agricultural Labor Productivity and Sustainability}

\begin{abstract}
Family farms contribute to agricultural production, and they make up about $98 \%$ of the businesses and $56 \%$ of agricultural production in the world. Agriculture in Turkey is a sector, which is providing employment for approximately 5.5-6 million people in 3 million agricultural holdings is mostly formed by small-scale family enterprise. Agricultural sector includes $21 \%$ of the employment and approximately $7.5 \%$ of Gross Domestic Product (GDP). The low level of GDP and a high level of employment rate indicate the low efficiency in agriculture. This fact is a result of several factor, such as density of small sized agricultural administrations, effectiveness in economical organization in agriculture, unavailability of widening usage of advanced technology among all farmers, less availability of social facilities such as education, health in rural areas and inability of effective usage of resources. In this study, strong and weak parts of family farming in Turkey shall be determine and it shall be shown that an economical organization is required for solution of structural problems in farming and for recovery of weak points of family farming and solution proposals are presented.
\end{abstract}

Key Words: Family farming, Productivity, Sustainability

\section{Giriş}

Aile çiftçiliği birçok boyutunun olması nedeniyle tanımlanması kolay olmayan bir kavramdır. Birleşmiş Milletler Gıda ve Tarım Örgütü (FAO) bir çalışmasında aile çiftçiliğinin tanımı üzerine yoğunlaşmış ve her biri aile çiftçiliğinin farklı karakteristik özelliklerini 
ifade eden 36 farklı tanımlama ile karşılaşılmıştır. Bu nedenle, genel kabul görmüş bir tanımlama yapmak çok kolay olmamakla birlikte, aile çiftçiliğinde en önemli unsurların aile işgücü olduğu, kararları aile bireylerinin verdiği, gelirin önemli bir kısmının tarımsal faaliyetten sağlandığı ve herhangi bir büyüklük sınırlamasının olmadığını söylemek mümkündür (Anonymous, 2014).

Türkiye'de de tarım işletmeleri aile işgücü ağırlıklı bir yapıda üretim faaliyetlerine devam etmekte ve bu işletmelerin asıl geçim kaynağını tarım oluşturmaktadır.

Türkiye'nin sahip olduğu iklim ve doğal koşullar bölgeler arası üretim deseninde önemli farklııklar yaratmaktadır. Böylelikle, bölgelere özgü ürünler önemli bir geçim kaynağı olarak ortaya çıkmakta ve tarım dışında istihdam imkânlarının azlığı ve nispeten düşük eğitim düzeyi tarımsal üretime devamı zorunlu kılmaktadır. Bu nedenle, Türkiye'de tarım işletmelerinin önemli bir bölümü geçimlik aile işletmeleri olarak faaliyetlerini devam ettirmekte ve sermaye birikimi de yapılamadığı için işletmeler ticari boyuta ulaşamamaktadır. Buna karşın; tarımsal faaliyet, aile intiyaçlarının karşılanabilmesi ve kente kontrolsüz göçün önlenebilmesi bakımından halen önemli bir sosyal olgu olmaya devam etmektedir.

Türkiye'de tarım işletmelerinin ortalama arazi genişliği 6 hektar olup, \%67'sinde bitkisel üretim ve hayvancılık bir arada yapılırken, sadece hayvancilık yapan işletme sayısı ise \%3'tür. Bölgelere göre değişmekle birlikte bitkisel üretimde ortalama çalışılan gün sayısı 209 olup, yıllık iş saati 1672 saat/işgücü ile $A B$ ortalamasından düşüktür (TUik, 2001). Buna karşın Türkiye'de halen tarımda aile işletmelerinin hâkim olduğu emek yoğun üretim öne çıkmakta ve en önemli üretim faktörü işgücü olmaya devam etmektedir. Bu durum özellikle hasadın elle yapıldığı, emek yoğun üretim gerektiren sebze ve meyve üretiminde daha önemli olmaktadır. İşletmenin gelirini çeşitli riskler karşısında korumak için de üretim deseninin çeşitliliği ve hayvancılık önem taşımaktadır.

Son yıllarda artan küreselleşme girişimleri rekabeti artırmakta ve bu süreçte kalite unsurlarının yanı sıra birim girdi başına verimlilik de belirleyici olmaktadır. Dünya ekonomisindeki gelişmelerin aynı ürünü daha ucuza temin edebilecek olanakları sağlamasına karşın, savaş ve kriz gibi olağanüstü dönemler nedeniyle ülkelerin kendine yeterlilikleri halen önemini korumaktadır. Bu nedenle, artan rekabet koşulları tarımsal işletmelerin ölçek ekonomilerine uygun olarak üretimde bulunmalarını zorunlu kılarken, gıda güvenliği/güvencesi, ekolojik-sosyalekonomik sürdürülebilirlik açısından da aile işletmelerinin önemi artmaktadır. Aile çiftçiliği her şeyden önce özellikle gelişmekte olan ülkelerde bir varoluş konusu ve sürdürülebilirliğin garantisi olarak görülmektedir. Doğal kaynakların sınırlı olması ve bu nedenle bunların gelecek kuşaklara ulaşmasının da ancak dikkatli kullanım ile mümkün olabileceği bilinmektedir (Anonymous 2014). Bu nedenle tarım sadece ekonomik açıdan değil sosyal olarak da önemli görülmekte ve tüm ülkelerde desteklenmektedir.

Türkiye'de ise tarım ürünlerinin uluslararası rekabet açısından temel güçlüğü işletme ölçeği ve verimlilikteki düşüklüktür. İşletme ölçeğinin küçüklüğünün yanı sıra bunun dezavantajlarını ortadan kaldıracak veya azaltacak bir örgütlenme düzeyine ulaşılamamış olunması da halen önemli bir sorundur. 
Türkiye'de 2000 yılında tarımda istihdam başına gelir tüm sektörler ortalamasının \%34.9'u iken 2015 yılında \%43.3 olarak gerçekleşmiş ve aynı dönemler içinde tarımda istihdam başına gelir 1.89 kat, tüm sektör ortalamasında istihdam başına gelir ise 1.5 kat artış göstermiştir. Buna göre aynı dönemler içinde tarımda istihdam başına gelir tüm sektör ortalamasından fazla artış göstermiştir (TUiK, 2016).

Bu çalışmada, Türkiye'de aile çiftçiliğinin mevcut durumu ve işgücü verimliliği dikkate alınarak tarımsal üretimde sürdürülebilirliğin sağlanma koşulları incelenmektedir. Bu amaçla, Türkiye'de tarımdaki yapısal sorunların çözümünde ve aile çiftçiliğinin zayıf yönlerinin giderilmesinde ekonomik bir örgütlenmenin gerekliliği ve çözüm önerileri anlatılmaktadır.

\section{Materyal ve Metot}

Çalışmanın ana materyalini Gıda Tarım ve Hayvancılık Bakanlığı (GTHB), Türkiye İstatistik Kurumu (TUiK), Birleşmiş Milletler Gıda ve Tarım Örgütü (FAO) ve Avrupa Birliği (AB) Çiftlik Muhasebe Veri Ağı (FADN) verileri oluşturmaktadır. Ayrıca, daha önce yapılmış bilimsel çalışmalar da incelenmiştir. Çalışmada, prodüktivite değer olarak hesaplanmış ve alana birim işgücü masrafı karşılığında elde edilen üretim değeri ve net gelir dikkate alınarak bulunmuştur. Birim alana işgücü masrafları ve ürünlerin üretim değeri Tarımsal Ekonomi ve Politika Geliştirme Enstitüsü (TEPGE) tarafından yapılan ürün maliyet çizelgelerindeki Türkiye ortalama verileri kullanılarak elde edilmiştir. Üreticilerin üretim faaliyetlerini ekonomik olarak sürdürebilmeleri ve rekabet edebilmeleri ise çiftçi eline geçen ürün fiyatlarının en azından maliyetleri karşılaması ve geçimini sağlayacak kadar da bir karın oluşmasına bağıı olmaktadır. Bu nedenle $A B$ ile karşılaştırma yapmak amacıyla ürünlerin çıktı/girdi oranları da kullanılmıştır.

\section{Araştırma Bulguları}

\section{Türkiye'de Aile Çiftçiliği}

Aile çiftçiliğinin birçok boyutunun olması çok sayıda tanımlamaya neden olmakla birlikte, işletmedeki işin esas olarak aile işgücü tarafından yapılması ve ailenin işletmeyi kendi hesabına yönetmesi önemli bir göstergedir (Anonymous, 2013). Aile işletmesinin tanımlamasında önemli olan göstergeler; işletmede işin kim tarafından yapıldığı, önemli kararları kimin verdiği, araziye ve altyapıya kimin sahip olduğu, işletmenin nasıl finanse edildiği, riski kimin üstlendiği, aile gelirinin nereden kaynaklandığı, aile ve işletme arasındaki bağlantılar ve işletme devrinin nasıl planlandığıdır (Anonymous, 2014). Buradan görüldüğü gibi aile çiftçiliği tanımı içinde işletme büyüklüğü bir kriter olarak yer almamaktadır. Zira dünyada yaklaşık 500 milyon olan aile işletmelerinin \%85'i özellikle de Afrika ve Asya'da 2 hektardan daha küçük arazileri işletirken, $A B^{\prime}$ de ortalama işletme genişliği 14 hektar ve Latin Amerika'da 70 hektardır (Anonymous, 2013). Bu durum tarımsal prodüktivite bakımından eşit olmayan şartları ortaya çıkarmaktadır.

Aile çiftçiliği, aile temelli tüm tarımsal faaliyetleri kapsamaktadır ve kırsal kalkınmanın birçok alanı ile bağlantılıdır. Aile çiftçiliği; geleneksel gıda ürünlerinin korunmasına yardımcı olan, dengeli beslenme için imkan sağlayan, tarımsal biyoçeşitliliğin korunmasına katkıda bulunan, kaynakların sürdürülebilir şekilde kullanılmasını sağlayan bir yapı olarak ortaya çıkmaktadır (FAO, 2014). Genel olarak aile çiftçiliğinin güçlü yönleri; karar almada hızlı olması, gelecek nesillerin düşünülmesi, krizlere direnç göstermesi, bağımsızlık, 
yüksek motivasyon, iş yoğunluğu olması durumunda aile bireylerinin işlere yardım etmesi olarak ifade edilebilir. Zayıf yönleri ise sermayenin az olması, yetersiz ölçek ekonomisi, riski üstlenme, verasetteki güçlükler, uzmanlığın yerini genel bilginin almasıdır (Anonymous, 2013). Bunlara ilave olarak Türkiye'deki aile işletmelerinin zayıf olduğu konuların başında ekonomik örgütlenmedeki başarısızlıklar gelmektedir.

Türkiye'de tarımsal faaliyette bulunan aile işletmelerinin olumlu tarafları yanında bazı zorlukları ve sorunları da bulunmaktadır. Kaynak ve hammadde temininde karşılaşılan sıkıntılar, nüfusun yaşlanması ve çocukların arazileri terk etmesi, eğitim ve finansman hizmetlerinin eksikliği ve erişim güçlükleri, fiyat oluşum süreçlerine az ya da hiç katılamama durumları aile çiftçiliğinin temel sorunları arasında yer almaktadır (GTHB, 2014). Bunlara ilave olarak bankalara, politik kararlara ve diğer sektörlere bağlı olunması nedeniyle ortaya çıkan sınırlamalar, küresel rekabet baskısı ve sınırların açılması, iklim değişikliğinin etkisi, şehre göç, toplumun değişen değer yargısı, kadınların rollerinin tanınmasındaki yetersizlikler, ebeveynlerin beklentileri nedeniyle gelecek nesiller üzerindeki baskılar da aile çiftçiliğinin sınırlayıcı faktörleri olarak söylenebilir (Anonymous, 2014).

Türkiye'de aile çiftçiliği konusunda genel olarak üretim maliyetlerinin yüksekliği, eğitim yetersizliği, örgütlenme yetersizliği ve mevcut örgütlerin pazarlamada etkili olamaması, kooperatif bilincinin ve aidiyet duygusunun yetersizliği, aile çiftçilerinin piyasadaki fiyat dalgalanmalarından aşırı etkilenmesi gibi konulardan kaynaklı sorunlar yaşanmaktadır. Türkiye'de aile çiftçiliğinin temel sorunu olan örgütleme sorunları ve bunların sonuçları Çizelge $1^{\prime}$ de verilmiştir.

Çizelge 1. Üreticilerin Ekonomik Amaçı̈ı̈rgütlenme Sorunları

Table 1.Problems of Economic Organization of Producers

\begin{tabular}{|c|c|c|}
\hline \multirow{4}{*}{ 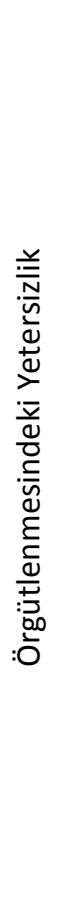 } & Nedenler & Sonuçlar \\
\hline & $\begin{array}{l}\text { 1. Düşük eğitim düzeyi } \\
\text { 2. Yayım çalışmalarının etkin } \\
\text { olmaması } \\
\text { 3. Başarılı iyi örneklerin çok az } \\
\text { olması }\end{array}$ & $\begin{array}{l}\text { 1. Yeterli bilincin oluşmaması, küçük çiftçiler için } \\
\text { örgütlenmenin öneminin algılanamaması } \\
\text { 2. Önder çiftçi eksikliği } \\
\text { 3. Kadınların işletme dışı işlerde aktif olmamaları } \\
\text { 4. Yetersiz tanıtım ve bilgilendirme } \\
\text { 5. Farklı bir imajın algılanması (siyasi çıkar vs.) } \\
\text { 6. Güven eksikliği } \\
\text { 7. İletişimin zayıflaması }\end{array}$ \\
\hline & Etkiler & Sonuçlar \\
\hline & $\begin{array}{l}\text { 1. Finansman yetersizliği } \\
\text { 2. Çiftçinin tek başına pazarlama } \\
\text { kabiliyetinin zayıflaması } \\
\text { 3. Girdilerin yüksek fiyata } \\
\text { alınması }\end{array}$ & $\begin{array}{l}\text { 1. Tarımsal ve teknolojik gelişmeler konusunda bilgilenme } \\
\text { ve bunları kullanmada yetersizlik (iTU, izlenebilirlik, } \\
\text { bilinçsiz gübre, ilaç kullanımı vs) } \\
\text { 2. Danışmanlık hizmeti alınamaması } \\
\text { 3. Taşıma ve depolama imkanlarının yetersizliği } \\
\text { 4. Kalitenin düşmesi } \\
\text { 5. Maliyetlerin artması (Aracı sayısının artması, kayıpların } \\
\text { artması, tüketici rantının azalması, kar marjının } \\
\text { düşmesi/düşük fiyat) } \\
\text { 6. İhracat şansının azalması }\end{array}$ \\
\hline
\end{tabular}




\section{İsgücü Prodüktivitesi}

Türkiye'de kırsal nüfusun ve istihdamda tarım sektörünün payı zaman içerisinde azalmakla beraber önemini sürdürmektedir. İstihdam edilenlerin 1990 yılında \%46'sı tarım sektöründe çalışırken, 2015 yılında \%20.6'sı tarım sektöründe çalışmaktadır. İstihdamda tarım sektörünün payı son 20 yılda yaklaşık \%45 azalmasına rağmen, halen çalışan 5 kişiden biri tarım sektöründe istihdam edilmektedir (TUiK, 2016).

Türkiye'de ekim alanı ve bitkisel üretim miktarı bakımından ilk sırada yer alan buğdayda toplam masraflar içinde işgücü maliyetinin payı İç Anadolu Bölgesinde \%2.7\%4.0; arpada \%2.8 - \%3.6 arasındadır. Tarla tarımında yoğun işgücüne ihtiyaç duyulan şeker pancarında ise aynı bölgede bu oran \%12.4 ile \%15.6 arasında değişmektedir (TEAE, 2001). Sebze tarımında domatesin işçilik masrafları açıkta üretimde toplam üretim maliyetinin \%34 ile \%49 arasında değişmekte, örtü altı tarımında ise yüksek girdi maliyetleri nedeniyle işgücü masrafı \%6'ya kadar inebilmektedir (Keskin ve ark., 2010). Üretici geliri bakımından ürün maliyetleri kadar ürün fiyatlarındaki istikrar da önemli olmakta, fiyatlardaki aşırı dalgalanmalar gelirde istikrarsızlığa neden olmakta ve üretim desenini de etkilemektedir.

Türkiye özellikle domates, havuç, karpuz, kiraz, elma ve kavunda ${ }^{1}$ iyi durumda görülmektedir. Maliyet çalışmaları yapılan diğer sebzelerde de 2009/2012 yıllarında çıktı/girdi oranları ortalama 2'nin üzerinde olup aynı yıllarda en düşük çıktı/girdi oranına sahip olan ürün 1.6 ile kuru soğandır (Keskin, 2011). Ancak ürün fiyatlarındaki, verim ve maliyetlerdeki değişikliklere göre yıllara göre

${ }^{1}$ GSÜD/masraflar oranı 2' nin üzerinde bulunmuştur. prodüktivite de farklılık göstermektedir. Bununla birlikte genel olarak tarla bitkileri üretiminin geniş alanlarda yapılıyor olması ve genellikle sebze tarımı kadar emek yoğun üretimi gerektirmemesi işgücü prodüktivitesi dışında diğer faktör verimliliklerinin burada daha önemli olduğunu göstermektedir.

Keskin ve Dellal tarafından 2010 yılında yapılan bir çalışmaya göre Türkiye'de tarımsal üretimde yılda ihtiyaç duyulan işgücünün yaklaşık \%44'ünü tarla tarımı, \%34.3'ünü sebze ve meyvecilik, \%12.7'sini büyük ve küçükbaş hayvancllık ve \%9'unu (nadas, küçükbaş vs) diğer üretim faaliyetleri talep etmektedir. Mülga Köy Hizmetleri Genel Müdürlüğü'nün yaptığı bir başka çalışmada ise bitkisel ürünlerde birim alana en yüksek işgücü talebi kiraz ve domateste en düşük ise buğday ve arpada bulunmuştur. Benzer sonuçlar Keskin tarafından 2011 yılında yapılan çalışmada da tespit edilmiş olup birim alandaki işçilik masrafları en yüksek domates, elma ve kirazda gerçekleşmiştir. Türkiye'de işgücü prodüktivitesinin en yüksek olduğu ürünler ise 2012 yılında kiraz, karpuz, elma ve domates olmuştur (Şekil 1).

Türkiye'de tarla bitkileri üretimi işletmelerin hem öz tüketimi hem de gıda güvencesini sağlama bakımından öne çıkarken, meyve ve sebze üretiminin daha çok pazara yönelik bir üretim olduğu ve ailenin gıda güvencesini sağladığı görülmektedir. Hektara en yüksek gelir 2011 yılında domates, kiraz ve elmada elde edilmiştir (Keskin, 2011). İşgücü talebi en yüksek olan ürünlerin alan gelirlerinin de en yüksek olduğu ve tarımda toplam prodüktivite artışında özellikle fazla işgücü gerektirmeyen mekanizasyonun yoğun olduğu tarla bitkilerinde verimlilik artışının önemli olduğu söylenebilir. 


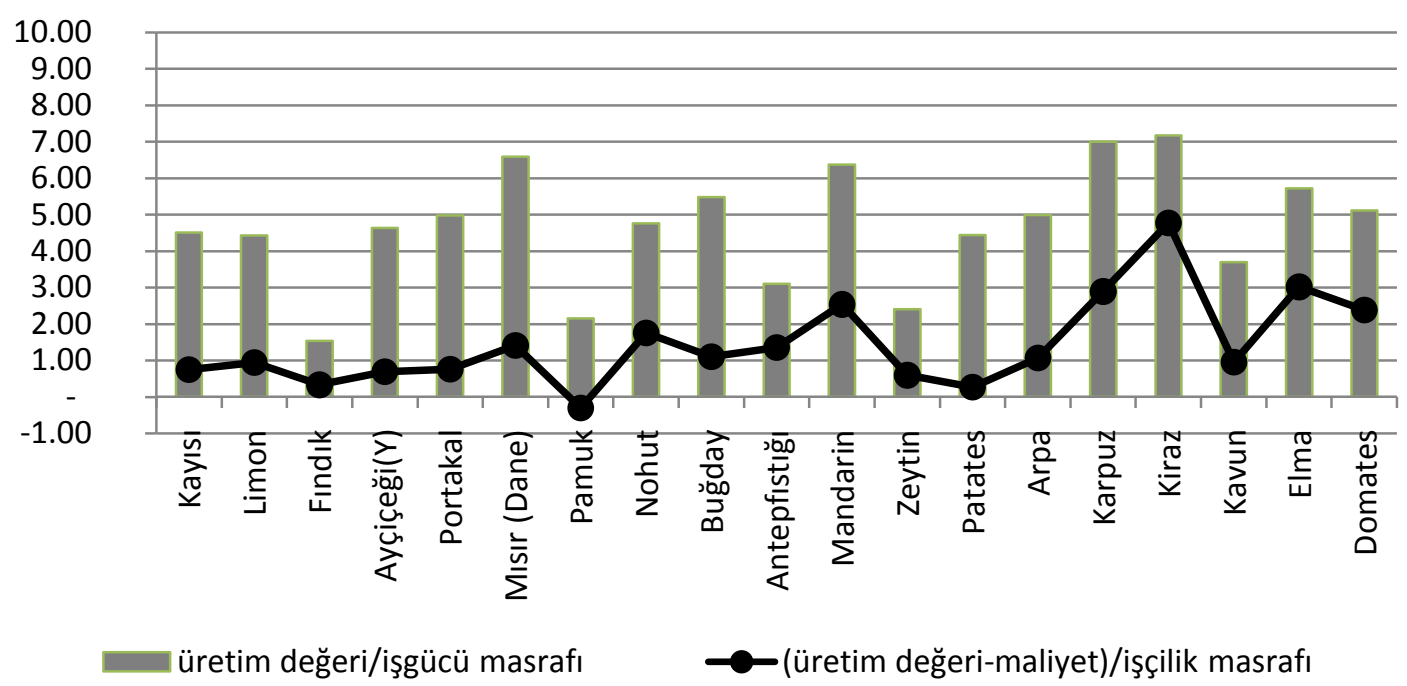

Şekil 1. Önemli Bazı Ürünlerde İ̧̧ücü Prodüktivitesi (2012)

Figure 1.Labor force productivity in some important products (2012)

Kaynak: Yazar tarafından yapılan özel hesaplamalar.

AB FADN verilerine göre 1990-2012 yılları arasında toplam çıktı/toplam girdi ${ }^{2}$ oranları incelendiğinde sebze ve süs bitkileri yetiştiren işletmelerde İtalya'nın (2) en avantajlı ülke olduğu görülmektedir. İspanya'nın 1990 ve 2000 yıllarında 2 olan toplam çıktı/toplam girdi oranı 2009 yılından sonra 1'e düşmüş, Yunanistan'da bazı yıllarda 1 olan bu oran 2009, 2011 ve 2012 yıllarında 2 olarak gerçekleşmiştir. Portekiz'in ise 1 olan oranı 2010 yılında 2'ye çıkmıştır. Bu verilere göre İtalya ve Yunanistan bahçe bitkileri yetiştiriciliğinde verimliliği yüksek ülkelerdir. İspanya'nın ihtisaslaşmış bahçecilik işletmeleri son 20 yılda alan olarak büyük bir gelişme göstermesine karşın çıktı/girdi katsayısı 2'nin altındadır (Anonymous, 2015). Şekil 2'den bahçecilik faaliyetinde ihtisaslaşmış işletmelerdeki toplam işgücünün 2012 yılına göre yıllık $\mathrm{AWU}^{3}$ olarak i̇spanya (2.84) ve İtalya'da

\footnotetext{
${ }^{2}$ Toplam brüt üretim değeri/ özel masraflar+genel masraflar+amortisman+ (ödenen ücretler+faiz+kira)

${ }^{3} 1$ AWU (annual work unit) 1800 saattir. Tam zamanlı çalışan bir kişinin yıllık çalışma süresini ifade eder.
}

(2.66) birbirine oldukça yakın olduğu görülmektedir. Şekil 2'den italya'daki işletmelerin emek yoğun işletmeler olduğu ve bahçecilik işletmelerinde emek yoğun işletmelerin daha verimli çalıştığı söylenebilir. Türkiye'de ise 2001 Tarım Sayımı sonuçlarına göre esas işi tarımsal faaliyet olan hanehalkı dikkate alındığında, işletme başına 2.65 kişi düşmektedir.

\section{Türkiye'de Aile Çiftçiliğinin Sürdürülebilirliği}

Aile çiftçiliği, sağlıklı ve sürekli üretilen gıda maddeleriyle öz ihtiyaçların karşılanması ve aile için uygun bir gelirin sağlanması bakımından önemlidir. Aile içinde devamlılı̆ın sağlanması ile yöresel bilgilerin korunması, doğal kaynakların sürekli kullanılabilir olması da sağlanmaktadır. Böylece ekolojik, ekonomik ve sosyal bakımdan aile işletmesinin sürdürülebilirliğini 


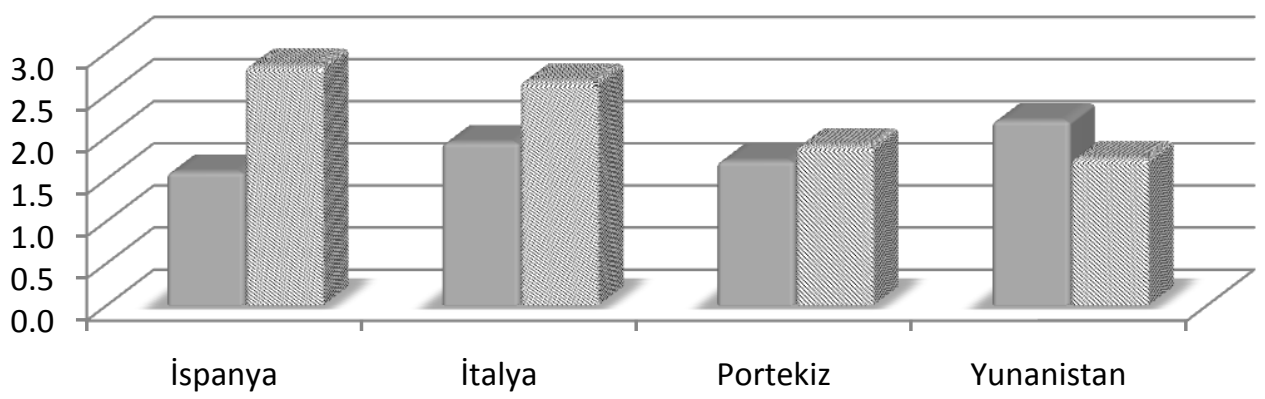

$\square 1990$

2012

Şekil 2. AB'de Bahçecilik Faaliyetinde intisaslaşmış İ̧letmelerde Toplam İ̧̧gücü (AWU, TF8)

Figure 2.Farms Specialized in Horticulture in the EU and Total Labour Input (AWU,TF8) Kaynak: (Anonymous, 2015)

sağlamak önemli olmaktadır (Anonymous, 2014; Anonymous, 2013). Ulusal düzeyde başarılı bir aile çiftçiliği tarımsal ve ekolojik koşullar ve bölgesel özellikler, uygulanacak çevre politikaları, pazarlama olanakları, doğal kaynakların varlığı, teknoloji ve yayım hizmetlerine erişim, tarımsal finansman olanakları, demografik, ekonomik, sosyokültürel koşullara erişim gibi birçok faktöre bağlı bulunmaktadır. Aile çiftçiliği, sosyal politikalarla desteklendiği durumda yerel ekonomilerin canlanması için de bir fırsat olarak görülmektedir (GTHB, 2014; FAO, 2014a). Bununla birlikte özellikle gelişmekte olan ülkelerde işletmelerin küçük ölçekli olması ve ekonomik güçlükler önemli sınırlayıcı faktörler olarak ortaya çıkmaktadır.

Her ülkede ekonomik, ekolojik ve sosyal kısıtlılıklar farklıık göstermekte olup, Türkiye'de aile ve sosyal bağların güçlü olması, geleneklere/yerel değerlere bağ|lıık, insanların yaşadığı çevreye bağlılı̆̆ı ve duyarlılık göstermesi aile çiftçiliğinin sürdürülebilirliği bakımından önemli göstergelerdir. Bir diğer önemli etken, Türkiye'nin sahip olduğu doğal ve ekolojik koşulların meyve/sebze yetiştiriciliğinde önemli avantajlar sağlamasıdır. Birim alana işgücü talebi yüksek olan bahçecilikte işgücü verimliliğinin tarla bitkileri yetiştiriciliğine göre yüksek olması da bu alanda önemli bir potansiyeli göstermektedir.

Türkiye'de aile çiftçiliğinin en önemli özelliği olan küçük işletmeler birçok sorunla karşı karşıya bulunmakta olup, Çizelge 1'de ifade edilen örgütlenme sorunu ise en temel sorun olarak karşımıza çıkmaktadır. Örgütlenmenin temel sorun olmasının ana nedeni ise özellikle ölçek ekonomisi gibi işletmelerin tek başlarına çözemeyecekleri sorunlar için bir araç olması ve Çizelge 2 'de görüldüğü gibi bunun sağlanması durumunda birçok sorununda çözülebilecek olmasıdır. Türkiye'de tarımın yapısal ve ekonomik sorunlarını çözmede ekonomik örgütlenme önemli bir araç olarak işletmelerin devamlılı̆ını sağlamada önemli olmasına karşın, mevcut örgütlenmedeki etkinsizlikler de bu sorunların çözümünü geciktirmektedir. Genel olarak, örgüt kültürünün uygulamaya gerektiği ölçüde aktarılmamış olması işletme yönetiminde başarısızlığın önemli nedenlerinden biri olarak görülmektedir (Ören ve ark. 2005). Türkiye'de de özellikle tarımda ekonomik örgütlenme kültürünün gelişmemiş olması ve üretim aşamasından tüketime kadar geçen tüm süreçte ekonomik örgütlenmedeki yetersizlikler tarım 
sektörünün temel sorunlarının başında gelmektedir (Keskin ve ark., 2010).

Türkiye'de tarımda örgütlenme modeli ekonomik örgütlenme, politika oluşturma amaçı̈ı örgütlenme ve mesleki örgütlenme şeklindedir. Kooperatifler, üretici birlikleri ve ziraat odalarından oluşan bu üçlü yapı içerisinde kooperatifler; çiftçinin ekonomik kolu, üretici birlikleri; politika, yönlendirme ve lobi oluşturma kolu, ziraat odaları ise hükümet ile çiftçi arasında köprü oluşturan mesleki koludur. Bu yapılanmada organizasyonların görev ve fonksiyonlarının birbirini tamamlar mahiyette olması önemlidir (Özdemir ve ark. 2011).
Türkiye'de tarımın önemli sorunlarının birçoğu Çizelge 2' de belirtildiği gibi ekonomik örgütler ve özellikle de tarımsal kooperatifler vasıtasıyla çözülebilir niteliktedir. Nitekim gülyağı, tiftik ve yaş koza üretiminin sürdürülebilirliğinde kooperatifler önemli bir role sahiptir. Kooperatiflerin etkinleştirilmesi ve özellikle tarımda örgütlenmede kadın potansiyelinin de etkin hale getirilmesi ile üretim yapılırken, aile bireylerinin yerelde istihdamı da sağlanmış olmaktadır. Bu nedenle yeterli etkinliğe sahip olmayan kooperatiflerin etkinleştirilmesi ve özellikle tarımda örgütlenmede kadın potansiyelinin de etkin hale getirilmesi ile başarı sağlamak mümkündür.

Çizelge 2. Üreticilerin Ekonomik Amaçlı Örgütlenme Sorununun Çözümü

Table 2. Solution of theProblems of Economic Organization of Producers

\begin{tabular}{|c|c|c|}
\hline \multirow{4}{*}{ 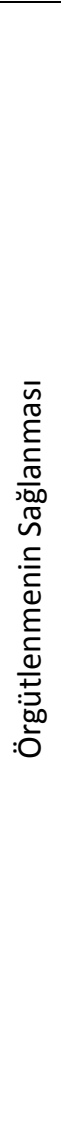 } & Ana Faaliyet & Alt Faaliyetler \\
\hline & $\begin{array}{l}\text { 1. Örgütlenmenin teşvik } \\
\text { edilmesi }\end{array}$ & $\begin{array}{l}\text { 1. Etkin eğitim ve yayım çalışmaları } \\
\text { 2. Kadınların aktif olarak örgütlenme faaliyetlerinde yer } \\
\text { almaları } \\
\text { 3. Başarılı örneklerin ödüllendirilmesi } \\
\text { 4. Başlangıçta mali destek sağlanması } \\
\text { 5. Teknik ve hukuki yardım, danışmanlık hizmeti } \\
\text { 6. Örgütlenme bilincinin oluşması }\end{array}$ \\
\hline & NIHAI SONUÇ & \\
\hline & $\begin{array}{l}\text { 1. Pazar odaklı üretim } \\
\text { 2. Güçlü finansman yapısı }\end{array}$ & $\begin{array}{l}\text { 1. Girdilerin uygun fiyata temini } \\
\text { 2. Pazarlamada etkin olma } \\
\text { 3. Depolama, taşıma, paketleme ve işleme tesislerinin } \\
\text { kurulması } \\
\text { 4. ITU, izlenebilirlik ve AB'ne uyumun kolaylaşması } \\
\text { 5. Aracıların azalması } \\
\text { 6. Kayıpların azalması } \\
\text { 7. Kalite ve standartlarda artış } \\
\text { 8. Rekabet gücünde artış } \\
\text { 9. Maliyetlerde azalma } \\
\text { 10. Ürünlerin hak ettiği fiyattan satışı } \\
\text { 11. Üretici gelirlerinde artış } \\
\text { 12. İhracat şansında artış }\end{array}$ \\
\hline
\end{tabular}

Kaynak:(Keskin ve ark. 2009) 


\section{Tartışma ve Sonuç}

Türkiye'de tarım işletmelerinde en fazla bulunan üretim faktörü işgücü, en yetersizi ise sermayedir. Artan küreselleşme girişimleri ile ulusal ve uluslararası pazarlarda rekabet edebilmek için kaynakların etkin kullanılması gelecekte var olabilmenin koşulu olarak belirmektedir. Bu nedenle, tarım işletmelerinde işgücünün etkin kullanımı ve gelir düzeyindeki artış rekabet şansını artıracağı için önemlidir.

Türkiye, uygun iklim koşulları nedeniyle birçok tarım ürününün yetişebildiği ve bazı ürünlerde de dünya liderliği bulunan ülkelerdendir. Meyve ve sebze üretiminde dünyanın önemli ülkeleri arasında yer almakta ancak, özellikle işgücü talebi düşük olan tarla bitkilerinde birim alandaki verimliliğin düşük olması da önemli bir dezavantaj olarak görülmektedir.

Birim alanda verimliliğin düşük olmasında işletme ölçeği, ekonomik anlamda örgütlenmedeki zayıflık, tarımsal faaliyetlerle uğraşanların eğitim düzeyi ve yeterli sermaye birikimi sağlanamaması gibi birçok faktörün etkisi vardır. Bu durum çiftçi eline geçen geliri düşürmekte ve işletmelerin rekabet şansını da azaltmaktadır. Türkiye'de tarım işletmelerinin ölçekten kaynaklanan mevcut sorunlarının çözümü ve küçük aile işletmelerinin varlıklarını devam ettirebilmeleri tarımda örgütlenme, özellikle de kooperatifler yoluyla sağlanabilecektir.

Türkiye açısından ekonomik değeri yüksek olan ve ağırlıklı olarak dış ticarette değerlendirilen fındık, incir, üzüm, zeytin ve narenciyede üretimin halen küçük aile işletmeleri tarafından yapılıyor olması önemlidir. Ölçek sorununa rağmen küresel etkilere karşı rekabet edebilmeyi başarmış ve dünya ticaretinde söz sahibi olunan bu ürünlerde üreticilerin örgütlenmiş olmaları etkili olmuştur.

Bu çalışmada, ürünlerin kalite özellikleri dikkate alınmadan bitkisel ürünlerde işgücünün verimliliği ve işletmelerin sürdürülebilirlikleri incelenmiştir. Buna göre, yoğun emek gerektiren ve birim alana işgücü talebi yüksek olan meyve ve sebze üretiminde işgücü verimliliği yüksek bulunmuştur. Ürün fiyatları ve maliyetler arasındaki oranların 2011 yılında en yüksek domates ve kirazda 2'nin üzerinde olduğu, en düşük ise kayısı ve limonda olduğu belirlenmiştir. Türkiye'de işgücü prodüktivitesinin en yüksek olduğu ürünler 2012 yılında kiraz, karpuz, elma ve domates olmuştur.

Rekabet edebilirlik bölgesel ve ulusal olarak yüksek ve artan bir yaşam standardı (refah) ve sürdürülebilir düzeyde yüksek bir istihdam oranına ulaşmak olarak tanımlanmaya başlanmıştır. Prodüktivitedeki artış ise rekabeti artırarak gelir artışı sağlayacağı için özellikle geri kalmış bölgelerde istihdam oranını olumsuz etkilemeden prodüktiviteyi artıran bir politika geliştirilmesi önemlidir. Bu nedenle, tarım dışı istihdam yaratma imkanının sınırlı olduğu Türkiye'de, tarımda istihdamın azalmasından çok etkinleştirilmesi, daha verimli kullanılmasını sağlayacak önlemlerin öne çıkması önemlidir.

\section{Kaynaklar}

Anonymous, 2015.

http://ec.europa.eu/agriculture/rica/data base/database de.cfm, Erişim tarihi: 19.01.2015

Anonymous, 2014. InternationalenJahr der bäuerlichenFamilienbetriebe 2014. http://ec.europa.eu/agriculture/consultati ons/family-farming/contributions/swissiyff-committee_de.pdf, Erişim tarihi: 19.01.2015 
Anonymous, 2013. Situationsbericht, Erfolgsmodell der bäuerliche Familienbetrieb, $\quad$ http://www.sbvusp.ch/fileadmin/sbvuspch/05 Publikatio nen/Situationsberichte/140103 SBV Situa tionsbericht.pdf, Erişim tarihi: 19.01.2015.

Anonymous, 2008. "Bestimmungsfaktoren der realenKonvergenz, Produktivitaet, Wettbewerbsfaehigkeitundwirtschaftliche Entwicklung", http://ec.europa.eu/regional policy/sourc es/docoffic/official/reports Lpdf/p141 de.pdf; Erişim tarihi: 02.11.2008.

FAO 2014. 2014 International Year of Family Farming, http://www.fao.org/familyfarming-2014/home/what-is-familyfarming/en/, Erişim tarihi: 10.11.2014.

FAO 2014a. International Year of Family Farming 2014, Master Plan (final version), (30 May 2013);

http://www.fao.org/fileadmin/user uploa d/iyff/docs/Final Master Plan IYFF 2014 30-05.pdf, Erişim tarihi: 10.11..2014.

GTHB, 2014. Uluslararası Aile Çiftçiliği Yılı 2014. http://www.tarim.gov.tr/ABDGM/Link/46/ Uluslararasi-Aile-Ciftciligi-Yili, Erişim tarihi: 10.11.2014.

Keskin, G., 2011. AB'de İhtisaslaşmış Tarım İşletmeleri- Sebze ve Süs Bitkileri-, TEPGE Bakış, Nüsha : 6, Aralık 2011, Ankara.

Keskin,G.,Dellal, i., $2010 . \quad$ Agricultural Employment and Labour Force Demand in Turkey, Actual Problems of Economics, No 11(113), s. 277- 285.

Keskin,G.,Tatlıdil, F.F., Dellal, İ., 2010. An Analysis of Tomato Production Cost and Labor Force Produktivity in Turkey, Bulgarian Journal of Agricultural Science (BJAS), Volume 16 (No 6), 692-699.

Keskin, G., Özüdoğru, T., Nazlı, C.,Berkum, S.van 2009. Sectoral Analysis: Dairy, Tomato, Cereal, Poultry (Editors ilkay Dellal and Siemen van Berkum), Turkish Tomato Sector Analysis, TEAE Publication number: 171, pp:59-91.

KHGM, 2005, “Türkiye'de Üretilen Tarım Ürünlerinin Üretim Girdileri Rehberi", KHGM Yayın No: 104, Ankara.

Ören, K., Erdem, B., Kaplan, M., 2005. Örgütsel Kültürün İşgücü Verimliliğine Etkisi, Kamuİs; C:8, S: 2/2005.

Özdemir, G., Keskin,G., Özüdoğru, H., 2011. Türkiye'de Ekonomik Krizler ve Tarımsal
Kooperatiflerin Önemi, Tekirdağ Ziraat

Fakültesi Dergisi, Cilt 8(1), 101- 113.

TEAE, 2001, "Türkiye'de Bazı Bölgeler İçin Önemli Ürünlerde Girdi Kullanımı ve Üretim Maliyetleri", Proje Raporu 2001-14, TEAE Yayın No: 64, Ankara.

TEPGE, 2012. Bitkisel Ürün Maliyetleri, (Yayınlanmamış).

TUik, 2001. 2001 Genel Tarım Sayımı Tarımsal İşletmeler (Hanehalkı) Sonuçları, http://www.tuik.gov.tr, Erişim tarihi: 01.12.2014.

TUiK 2016. Temel İstatistikler, www.tuik.gov.tr, Erişim tarihi: 05.10.2016. 